\title{
Legal Literacy Training of College Students Based on New Youth's Activities in Rural Areas
}

\author{
Jun $\mathrm{Gao}^{\mathrm{a}}$, Xuemei Liu ${ }^{\mathrm{b}}$ and Xuefen Hong ${ }^{\mathrm{c}}$ \\ Wuhan Business University, Wuhan, Hubei, China, 430056 \\ awbu_gaojun@163.com, b2519154683@qq.com, c25638164463@qq.com
}

Keywords: Legal Education, Ideological politics.

\begin{abstract}
This document explains and demonstrates how to improve college students' legal quality. In the cultivation of legal literacy of college students only theoretical education is often paid attention to. In order to effectively improve student's legal literacy, it is necessary to formulate corresponding practical links. The "New Youth to the Countryside" activity launched by Wuhan city provides a good platform for the practice of education of legal literacy of college students. Taking the "New Youth to the Countryside" activity as an example, this paper introduces how to improve the legal literacy of college students through practical teaching. This document also discusses how to make the "New Youth to the Countryside" activity play a greater role in the legal literacy of college education.
\end{abstract}

\section{Introduction}

The cultivation of legal literacy of college students is a key part of education, and it is also a key issue that the party and the state education departments have been paying attention to. College students need to be able to correctly exercise the rights accorded to citizens by the law, and set up the basic coordination of the law, and adapt to the requirement of the legal system construction. This is the basic goal of the legal system education of university students in China.

\section{Problems of legal literacy education}

\subsection{Overemphasis on theoretical teaching}

In the current education of university legal literacy, the teaching concept of "emphasizing theory over practice" still occupies a high proportion. Some legal literacy education workers only pay attention to the theory education in the classroom, but ignore the importance of practical teaching and other links. In addition, the college students' legal quality education in colleges and universities teaching idea and teaching organization only mostly revolves around the theory teaching, other forms of legal literacy education lack of systemic system design. ${ }^{[1]}$

\subsection{Practical teaching is seriously inadequate}

The Central Propaganda Department and the Ministry of Education jointly issued "on further strengthening and improving the opinions of the higher school ideological and political theory course" which emphasize to strengthen practice teaching. This document particular emphasis that all of the political lesson should arrange the practice teaching part including legal literacy education in colleges and universities. ${ }^{[2-3]}$

But in actual teaching, due to the influence of the following factors, such as, the lack of system design of legal literacy education practice teaching part, the insufficient investment of practical teaching funds, the practical education of legal literacy education is seriously insufficient.

\section{Practical teaching of legal literacy of college students}

In view of the importance of practical teaching part of the legal literacy cultivation of university students, some universities start the practical teaching in legal literacy teaching activities according to 
the characteristics and advantages of each school. Colleges have formulated practical teaching activities aimed at cultivating legal literacy. According to guiding students to pay attention to the legal spirit in practice, the analysis of specific legal cases observation, by putting forward a system of measures, such as legal solutions to improve university students' legal literacy has played a very positive role. At the same time, the practical teaching activities of legal literacy training have also received high praise from students. ${ }^{[4]}$

Taking Wuhan Business University as an example, in order to improve the teaching effect of students' legal literacy training and strengthen the practical teaching link of students' legal literacy training, the following measures are adopted:

a. Special invited local judges and prosecutors to school lectures on the rule of law and legal propaganda activities at the same time.

b. To carry out the "campus moot court competition" and other activities, let the student to participate in activities such as parties, defenders and judges.

c. Lead the students to visit the prison, the court etc. Make students listen to the explanation and report of relevant personnel.

d. Organize students to watch legal films and other legal propaganda films.

\section{The relationship between "New Youth to the Countryside" and the practice teaching of College Students' legal literacy training}

In response to the national requirements for practical teaching of ideological and political education, organization in Wuhan city was carried out the activity of "New Youth going to the Countryside". This activity solves the problem of single form of ideological and political education, and deeply combines the actual situation of Wuhan's social development, providing a very good platform for Wuhan universities to carry out various forms of ideological and political education practice teaching. Therefore, the practical teaching of legal literacy training for college students can also rely on Wuhan's activities of "New Youth going to the Countryside".

In February 2017, the activity of "new youth going to the countryside" was officially launched in Wuhan, aiming to promote the organic combination of new rural construction and ideological and political education in colleges and universities. While serving and contacting the masses of peasants, it also promotes the growth of college students. According to the overall arrangement of the activity of "new youth going to the countryside", Wuhan city will arrange more than 100 groups of college student service teams to settle in the villages of Caidian district, Jiangxia district, Huangpi district and Xinzhou district under the jurisdiction of Wuhan city to carry out assistance activities. More than 100 classes from Jianghan University, Wuhan Business University and other universities will participate in the preliminary activity, and the activity team will be settled in 107 natural villages in 22 towns. ${ }^{[5]}$

Wuhan "New Youth going to the Countryside "activities will carry out five major actions, including theoretical farming, scientific and technological support for agriculture, literary and artistic agriculture, loving care for farmers and ecological agriculture. Theoretical education farming operation requirement, organize and mobilize the youth Marxists in colleges and universities to cultivate engineering backbone students into an in-depth publicity and education activities of socialism with Chinese characteristics and the Chinese Dream. And it requests to comprehensively publicize the spirit of the 13th CPC congress and calls for rural masse to learn about the three rural police by theory teaching, panel discussions, online learning in order to guide its firm confidence, to master development situation, to establish opportunity consciousness and to make good use of benefit agriculture policy. Finally, it will make contribution for advancing agricultural modernization construction. ${ }^{[6-7]}$

It will be necessary to carry out the activity of "New Youth to the Countryside" and practical teaching link of legal literacy training for college students in view of the "New Youth to the Countryside" to the specific requirements of the agricultural operation activities in the theory combining the current situation of the rural areas the publicity is weak at the same time to strengthen college students' ability to understand laws and apply the laws. 


\section{The project of strengthening the legal quality training program of college students by activity of "New Youth going to the Countryside"}

In order to explore how to use activities to strengthen the legal literacy of college students, the article will take the legal publicity activities of the "New Youth to the Countryside" activity group in Wuhan Business University as an example. This paper explains in detail how to use the platform of "new youth to go to the countryside" to realize the combination of the practice education of legal literacy and the activities of supporting agriculture and benefiting farmers.

The academy of mechanical and electrical engineering and automotive services of Wuhan Business University is connected to the Baimashan Village in Caidian district during the activity of "New Youth to the Countryside". According to the specific situation of the village, first of all to investigate and visit the work to collect the common legal cases. Secondly, using various ways to excavate the legal knowledge involved in the above cases. Finally, helping the peasants learn the law through the publicity of the law. The specific steps and arrangements are shown in Table 1.

Table 1. Legal literacy education activities based on the activities of "New Youth going to the countryside"

\begin{tabular}{cll}
\hline Step & \multicolumn{1}{c}{ Activity content } & \multicolumn{1}{c}{ Font size and style } \\
\hline 1 & $\begin{array}{l}\text { To investigate the rule of law, common } \\
\text { public security cases and other disputes in } \\
\text { villages. }\end{array}$ & $\begin{array}{l}\text { Purpose of activity } \\
\text { collect materials were analyzed, and the } \\
\text { study involving legal knowledge. } \\
\text { Consult with relevant legal experts to discuss } \\
\text { and confirm the legal issues involved. }\end{array}$ \\
\hline & $\begin{array}{l}\text { Further understand the specific situation of the } \\
\text { aillage and collect cases for legal publicity }\end{array}$ \\
\hline 3 & $\begin{array}{l}\text { To produce legal publicity manuals for } \\
\text { classic case and distribute them to villagers } \\
\text { in their villages. }\end{array}$ & $\begin{array}{l}\text { Through the analysis of legal cases to let students } \\
\text { learn knowledge and a preliminary understanding } \\
\text { of how to solve the problem through legal } \\
\text { channels. }\end{array}$ \\
\hline
\end{tabular}

Through the above activities scheme, firstly, let students into the present situation of the rural awareness of the rule of law is at the grass-roots level, secondly, though literature survey and experts consultation to make the students learn how to use legal means to solve the problems, finally, through propaganda means that the villagers get certain legal education. This not only enables students to receive education and improve their legal literacy in the activities but also enables farmers to accept education.

\section{Measures to further improve the legal literacy of college students}

\subsection{Putting practical teaching into the compulsory link}

Through practical teaching, students in colleges and universities can better cultivate their legal literacy, so that students can truly understand legal concepts with vivid cases, and deepen their understanding of what they have learned in books. Through the activity of "New Youth to the Countryside", college students can participate in legal activities at the grassroots level, which provides a excellent way for college students to participate in legal practice.

However, the program is only for some students at some colleges and universities, and it doesn't cover all students. In order to let more students through the "New Youth to the Countryside" activity to accept the legal system education can consider to include the "New Youth to the Countryside" activity in the course "social practice" system, the compulsory course for and give the corresponding credits.

\subsection{Expanding the scope of participation}

The activity of "New Youth going to the Countryside "is only carried out in four colleges and universities in Wuhan at present, which plays a very positive role in enhancing students' quality, 
improving students' ideological and political consciousness, improving students' legal accomplishment and other aspects. Therefore, combined with the characteristics of Wuhan university it can be gradually popularized in Wuhan university. After sufficient argumentation, the opportunity is ripe, it can try to popularize to the national university.

\section{Summary}

This study carried out the practice of legal literacy education in colleges and universities through the activity of "New Youth going to the Countryside", the study shows that the formation of legal quality of college students largely comes from their perception of law in social practice, and only by actively or passively using law in practice can legal literacy be truly improved. College students have a strong thirst for knowledge and curiosity. In the legal practice teaching, students are actively guided to carry out legal practice activities by means of "new youth going to the countryside" activity, which can further improve the legal literacy of college students.

\section{Acknowledgment}

This research was financially supported by the Humanities and Social Sciences Research Project of Hubei Education Department (Grant NO. 18Z120).

\section{References}

[1] Ying Liu, Hua Deng. University legal system education in the view of harmonious society [J]. Higher Education and Academic Research. 2008, 3

[2] Opinions of the Propaganda Department of the CPC Central Committee and the Ministry of Education on Further Strengthening and Improving the Ideological and Political Theory Courses in Institutions of Higher Learning [R]. Documents of Ministry of Education No.2005-5. 2005,8

[3] Han Li. A Preliminary Study on the Teaching Method Reform of "Ideological and Moral Cultivation and Legal Basis" -- Taking "Legal Basis" as an Example [J]. Journal of Zhuzhou Normal University. 2007, 3

[4] Yuqiong Guo. Principles of Practical Teaching in Ideological and Political Theory Course [J]. School Party Building and Thought Education. 2017, 10

[5] Ruke Zheng, Xuexuan Hu. Wuhan "New Youth to the Countryside" Activity Was Launched $[\mathrm{N}] .2017,3,5$

[6] Program of "2017 New Youth Go to the Countryside in Wuhan" [R]. Documents of Wuhan Municipal Government No. 2017-4. 2017, 2

[7] Editing Group. Ideological and Moral Cultivation and Legal Basis [M]. Beijing: Education Press, 2013 